\title{
A Review of Water Quality and Pollution Studies in Tanzania
}

The coastal area of Tanzania (Fig. 1) encompasses a number of habitats that include coral reefs, mangroves, seagrass beds, sand banks, wetlands and beaches, among others. In addition to being essential linkages in the overall functioning of the coastal area, these coastal habitats support various resources both living and nonliving. In addition, for generations the coastal area has provided life support to coastal communities where such activities as fisheries and related activities have played an important role in the social and economic development of local communities. In recent years, coastal tourism and mariculture have emerged as being among the most important national economic activities. The well-being of these natural habitats and resources and the various activities taking place within or near coastal waters depend, to a large extent, on good water quality.

However, expanding coastal populations and emerging industrial activities are exerting ever increasing pressures on coastal waters thus negatively affecting water quality. As a result coastal pollution is increasingly becoming a major issue in Tanzania. Reports indicate that coastal waters fronting such cities and towns as Dar es Salaam, Tanga, Zanzibar, and Mtwara arc grossly polluted (1-4). Furthermore, landbased activities such as agriculture, industry, and mineral exploitation have further contributed to the degradation of coastal water quality. This paper gives a summary of the available in formation about water quality and pollution in Tanzania.

\section{WATER QUALITY RESEARCH IN TANZANIA}

Research in pollution and water quality does not have a long history in Tanzania. The earliest records found on this aspect were from the early 1970s. For example, a 1971 report by the Danish Isotope Center provides results of a feasibility study that assessed the water supply to Dar es Salaam. Another study, by Steinbach (5), reported on the relationship between industry and the environment in the Msimbazi Valley drainage area and, Ngoile et al. (6) discussed some aspects of aquatic pollution if) Tanzania. These studies were followed in the 1980 s by investigations on different aspects of the environment (7-9). Then beginning in the early 1990s, there was an upsurge of publications on the topic making this period by far the most productive in terms of studies on pollution and water quality in Tanzania.

In Dar es Salaam, Kondoro (10) assessed heavy metal $(\mathrm{Pb}, \mathrm{Cd}, \mathrm{Zn}, \mathrm{Cu}, \mathrm{Cr})$ distribution along Msimbazi River. Other studies include that of Wekwe et al. (II) who assessed heavy metal content of several species of algae along the coast of Dar es Salaam. Heavy metal pollution was also studied by Machiwa (2) who assessed anthropogenic input of $\mathrm{Fe}, \mathrm{Mn}, \mathrm{Zn}, \mathrm{Pb}, \mathrm{Cr}$, $\mathrm{Cd}$ and organic carbon in Dar es Salaam coastal sediments. Machiwa (12) also investigated the possibility of the occurrence of toxic materials (PCl1s) and organic carbon and pathogenic microbes in the marine sediments off Dar es Salaam.

Several pollution assessment studies have been carried out in Zanzibar, mostly in the waters fronting the Stone Town in the Zanzibar Municipality. Among the earliest such studies is that carried out by Van Bruggen (1) who measured water temperature, DO, conductivity, $\mathrm{pH}, \mathrm{BOD}$, COD, heavy metals, and faecal and tolal coli forms. The study was commissioned by the Zanzibar Department of Environment to facilitate the formulation of the Zanzibar Environmental Policy. This study was followed by that of Mohammed (3), who investigated pollution by industry and other users of chemicals in Zanzibar. Mohammed et al. (13) looked at the impact of pollutants (nutrients and coli forms) on the reefs fronting the Zanzibar Town. Another study was by Walvoord (14) who measured baseline concentrations of dissolved nutrients, BOD, salinity and dissolved oxygen at 14 sites in the same area. Johnstone and Suleiman (15) measured nutrient concentrations near the islets of Bawe and Chapwani (off the Stone Town). They also examined nutrient dynamics and community response to nutrient loading. Mmochi and Francis (16) undertook long-term monitoring of water quality also in the Stone Town area of Zanzibar. Studies conducted outside the Zanzibar Town area include those by Mmochi (17, 18), studying pesticide and nutrient pollution of groundwater in the Chwaka Bay,

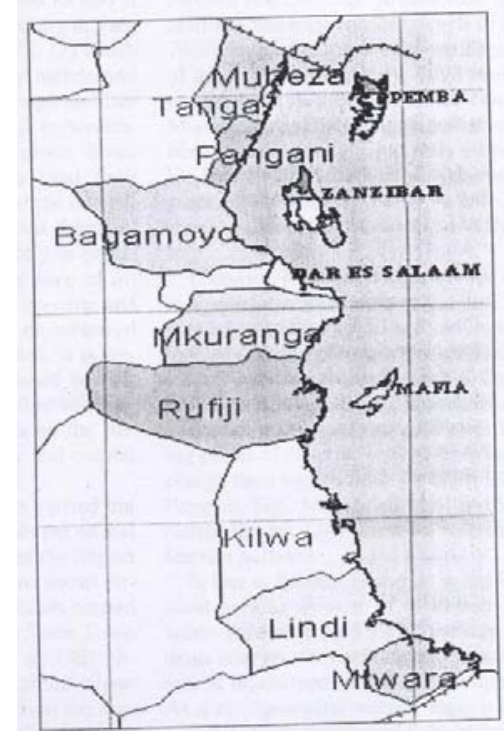

Figure 1. Map of Tanzania showing coastal districts

Pajc, Fumba, and Mahonda-Makoba basins in Zanzibar. At Maruhubi, Machiwa (19) measured lateral !luxes of organic carbon.

Many review articles have been written on the pollution problem especially in the Dar es Salaam area. Uronu (20) analyzed the development of the sewerage system in Dar es Salaam, from its construction in 1948 through its different extension phases in the 1970s. The report also assessed domestic sources of pollution along the coast of. Dar es Salaam. Another review of the development of the sewerage system of Dar es Salaam was prepared by Matiinez (21).

Other reviews include that of Bryceson et ell. (22) who assessed the state of (he marine environment in the East African Region, including Tanzania. In another study, Bryceson (23) reviewed some problems of marine conservation with particular reference to Tanzania. A comprehensive review of the sources of pollution on the Tanzania mainland was conducted by Mgana and Mahongo (24), who quantified all major human activities that contributed to pollution of the marine environment. A similar kind of review was prepared by 
Mohammed (25) who investigated landbased sources of pollution affecting coastal, marine and associated freshwater environments on the islands of Zanzibar. Other reports from Dar es Salaam are those by Bwathondi et al. (26) who compiled all available data at that time on pollution of the Msimbazi River and advised on the need for a comprehensive multidisciplinary research program to assess the problem. Mashauri and Mayo (27) discussed the potential impact or discharging raw sewage into the Indian Ocean. In Tanga, Shilungushela (28) made an inventory of destructive activities to the marine and freshwater bodies in the Tanga region.

Most of the information on water quality and pollution in Tanzania comes from areas in or around major towns and cities. Consequently, Dar es Salaam, Tanga, and Zanzibar received the most coverage. In this regard, geographical coverage of water quality studies in Tanzania can be best termed as very poor. It can be argued that the areas most affected by pollution are those that are located next to these densely populated towns and cities, hence the focus of studies. However, even in Dar es Salaam, Tanga, and Zanzibar, not all areas have been covered by these studies, both in terms of subject and geographic coverage. In Dar es Salaam, most studies have concentrated in the Msimbazi River and Creek and the harbor area, at the expense of other areas. The same can be said of Zanzibar and Tanga. In Zanzibar, the majority or water quality studies were carried out in the waters fronting the Stone Town in the Zanzibar Municipality. These include both baseline and monitoring studies. In Tanga, the studies carried out in that municipality targeted specific areas that are recipients of either municipal wastes or wastes from the local industrial facilities including a fertilizer factory. However, the 1993 study by Shilungushela (28) in Tanga looked at, among other things, pollution emanating from the agricultural sector in the area. Practically no other study has been conducted outside these areas. It is obvious then that there is a need to broaden the geographic coverage of water-quality studies to other parts of Tanzania where today virtually no information on this subject exists.

The subject area most covered by water-quality studies in Tanzania is pollution emanating from sewage waste. This reflects the previously mentioned fact that most studies have been concentrated near major population centers and the nation's concern over sewage pollution. Few studies have looked at other sources of water quality degradation and their impacts on the natural environment and on human health. Studies have mainly focused on nutrient loads and distribution, BOD and coliforms levels and other indicators of sewage pollution. Studies on heavy metal pollution and that emanating from organic compounds and agrochemieals arc few and far between. Among the few studies of this kind are included a study by Mmoehi and Mberek (29) who looked at trends in pesticide use and toxicity in Tanzania and those by Machiwa (2, 12) which assessed pollution by heavy metals and other toxic material. Both Tanga and Dar es Salaam have relatively high concentrations or manufacturing enterprises. Since few industries in Tanzania treat their wastes before they are discharged into the environment, it is obvious that these industries contribute significantly to pollution loads. Given the current pace of industrial development in the country and the fact that only few studies on industrial pollution have been conducted, it is important that more studies should be carried out to generate both baseline information as well as follow trends on the impact of these wastes on river and coastal water quality.

The majority of the studies carried out so far looked at pollution loads per se and noticeably few have examined the impact of pollutants on the natural or social environments. These include studies carried out in the waters fronting the Stone Town of Zanzibar where Bjork et al. (30) observed a reduction in coralline algae caused by sewage pollution from the municipality. Johnstone and Suleiman (15) reported increased community metabolism and gross production in the same area, which they attributed to excess loading of nutrients through sewage discharge from the municipality. Machiwa (21) examined the effects of sewage dumping on the levels and rate or mineralization or organic carbon in sediments of a partly polluted mangrove stand in Maruhubi in Zanzibar. Another study was by Kangwe (31) who studied the effects of mercury, lead, and cadmium on calcification rates of the reef-building calcareous algae Amphipora tribulis, while Shanmungam (7) assessed the impact of port development in Tanzania on the marine environment. Bryeeson (32) assessed the impact of effluent (domestic, industrial) disposal on the ecology of Dar es Salaam coastal habitats. Chande (33) identified and assessed the magnitude of activities that had an impact on the marine environment. Shunula and Ngoile (34) assessed the consequences of human activities on the marine environment of Zanzibar.

\section{THE STATE OF WATER QUALITY IN TANZANIA}

Several studies have shown that in general the coastal waters in many parts of Tanzania are in a relatively pristine condition. The exception is coastal areas bor- dering major tows and cities that are recipients of untreated municipal and industrial wastes and those areas receiving agricultural wastes. These include the main coastal towns of Dar es Salaam, Tanga, Mtwara and Zanzibar. In Zanzibar, faecal coliform and total coliform levels of up to $70 / 100 \mathrm{~m} \mathrm{I}$ and numerous thousands per $\mathrm{ml}$ of seawater, respectively, have been reported in the waters fronting the Zanzibar Municipality (27). Sewage pollution has been cited as being principally responsible for increased cases of waterborne diseases on the islands. These include diarrhoea, gastroenteritis, cholera and dysentery.

Likewise, it has been reported that there is a proliferation of macroalgae in Tanga coastal waters due to excess nutrient loadings from discharges from a fertilizer factory and from the municipality. Coastal pollution in Tanga is also attributed to discharge of effluents from sisal decorticating plants in the area. Up to 20 plants discharge their wastes onto the coast via the Pangani, Sigi, Mruazi/Mnyuzi, and Mkurumzi Rivers (28) some of which are heavily polluted.

In Dar es Salaam, domestic waste is the most serious source of pollution. The waste generated by $15 \%$ of the city residents who are connected to the sewer system is discharged into the sea untreated. As a result coastal waters, especially in the vicinity of the Dar es Salaam harbor, arc heavily polluted. Discharge of untreated sewage in Dar es Salaam has resulted in high faecal and total coliform levels in coastal waters. The situation is made worse by a broken sewer pipe, which discharges untreated sewage on sandy-mud flats near the harbor and is said to threaten invertebrates and fish $(22,23)$. It has also been reported that chlorinated organic compounds are present at alarming levels in the harbor areas as are heavy metals, e.g. $\mathrm{Pb}$, $\mathrm{Zn}$ and $\mathrm{Cu}$ (2). For many years, the harbor area suffered from oil pollution from the refinery at Kigamboni, and industrial wastes from Keko, Chang'ombe, Kurasini, Mtoni, and Temeke. These discharge heavy metal, pesticide, organic, and paint wastes into the nearby area (35). However, the refinery has now ceased operation.

Msimbazi River and Creek are also among the most polluted waterbodies in Dar es Salaam. The river and creek receive large quantities of untreated domestic wastes from the city's residents in addition to industrial wastes from various industries. The river and creek receive such pollutants as dyes and paint wastes and strong alkalis (from textile factories), oil, and tars, (from vehicle depots and power stations), organic wastes (from breweries and meat plants). Other industrial and agricultural chemicals that pol- 
late the river and creek include heavy metals, PCBs, cyanides, pesticides, and detergents (32). Table 1 and 2 give pollution loads in surface and ground water sources respectively in Dar es Salaam.

Other coastal areas of Tanzania outside the major cities and townships, though free from domestic wastes, do suffer from input of agricultural wastes, including pesticides and fertilizers, via rivers and streams. Most major rivers in the country drain agricultural lands and deposit their waste loads on the coast areas. Unfortunately, this area of concern has not received sufficient attention from researchers.

Vast amounts of sediment enter the coastal waters annually via the nation's river networks. Such inputs can be a result of natural events such as storm events and rains in upland areas, though poor agricultural practices have been known to playa leading role in water-quality degradation due to sedimentation (23). A direct consequence of sedimentation is the smothering of corals and other benthic organisms. Sedimentation also has a detrimental effect on social and economic potential of coastal waters causing the reduction of aesthetic value of the water thus making it less attractive for such activities as tourism as well as for general recreational activities.

In order to arrest this situation, several steps have been taken, aimed at combating the problem of pollution in Tanzania. Foremost of these is the adoption of national policies which set out the country's agenda that aims at curbing pollution of waterbodies. These include the National Environmental Policy that advocates the prevention and control of pollution of the marine and coastal waters, including that from land-based sources. This policy statement is supported by relevant legal instruments such as the Water Utilization (Control and Regulation)(Amendment) Act No. 10 of 1980 which provides legal powers for the application of temporary water quality standards for effluent and receiving waters. These include standards for direct discharge into receiving waters and those for indirect discharge via municipal sewer networks. However, there has been weak enforcement of this and other regulations resulting in continued pollution of coastal waters especially from land-based sources.

Management of waste is linked to that of clean water supply. For example, in Dar es Salaam, management of water supply and sewage is under the jurisdiction of a state run corporation, the Dar es Salaam Water and Sewerage Authority (DAWASA). For a long time this corporation, which assumed the role of provider of fresh water and disposal of wastewater at minimal cost, failed to provide ade-
Table 1. Pollution load to surface water resources ( $\mathrm{kg}$ day') In Dar es Salaam.

\begin{tabular}{lrrrrr} 
Type & $\begin{array}{r}\text { Industrial } \\
\text { effluent }\end{array}$ & $\begin{array}{r}\text { Pit } \\
\text { latrines }\end{array}$ & $\begin{array}{r}\text { Septic } \\
\text { tanks }\end{array}$ & $\begin{array}{c}\text { Without } \\
\text { facilities }\end{array}$ & Total \\
\hline BOD & 28330 & 15282 & 3275 & 9897 & 56784 \\
COD & 29904 & 16131 & 3457 & 10447 & 49776 \\
Suspended solids & 47216 & 25470 & 5458 & 16495 & 78429 \\
Dissolved solids & 83940 & 45280 & 9830 & 29325 & 138923 \\
Total N & 4145 & 2236 & 479 & 1448 & 6859 \\
Total P & 787 & 425 & 91 & 275 & 1302
\end{tabular}

Source: Sustainable Development Programme (1992)

Table 2. Pollution loads to groundwater sources $\left(\mathrm{kg} \mathrm{day}^{-1}\right)$ in Dar es Salaam.

\begin{tabular}{lcrrrrr} 
Type & No facility & $\begin{array}{c}\text { Pit } \\
\text { latrines }\end{array}$ & $\begin{array}{r}\text { Septic } \\
\text { tanks }\end{array}$ & $\begin{array}{c}\text { Sewer } \\
\text { domestic }\end{array}$ & $\begin{array}{r}\text { Losses } \\
\text { industry }\end{array}$ & $\begin{array}{c}\text { Total } \\
\text { (tonnes) }\end{array}$ \\
\hline BOD & 1100 & 15282 & 7641 & 1221 & 1899 & 27 \\
COD & 1161 & 16131 & 8068 & 1289 & 11994 & 29 \\
Suspended & 1833 & 6116 & 3832 & 2035 & 3148 & 18 \\
solids & & & & & & \\
Dissolved solids & 3258 & 9757 & 61128 & 3618 & 5596 & 196 \\
Total N & 120 & 4829 & 3018 & 3618 & 5596 & 10 \\
Total P & 23 & 915 & 572 & 34 & 52 & 2
\end{tabular}

quate services to its customers. Moreover, ed untreated in the nearby coastal waters. The DAWASA's approach proved to be very cost same situation prevails in other towns along intensive and was characterized by persistent the coast.

losses. However, The Water Laws For the long-term sustainability of the (Miscellaneous amendments) Act of 1999 has coastal zone and its resources, it is important to enabled in-depth institutional reform within develop better sewerage facilities including DAWASA. Under current laws, the authority treatment plants. However, given the potentially will be able to sub-contract technical and huge investment requirements for secondary or commercial operations of services to tertiary waste-treatment, it is recommended that commercial Private Operators under a 10-year there should be installed at least primary waste Lease Contract. The Operator will be treatment facilities in the major cities to responsible for operational management of the facilitate initial waste treatment before services as well as to provide initial capital discharge. Tourist hotels and industrial plants (36). It is hoped that this arrangement will help should have their own onsite treatment improve services and promote cost recovery. facilities to reduce waste loads in the public

\section{RECOMMENDATIONS}

Not a single city or town in Tanzania has sewage-treatment facilities. Invariably, waste from these cities/towns is discharged untreated into the environment, mainly into coastal waters via local sewer networks and rivers. In most cities and towns, sewer networks are either nonexistent, inadequate or in an advanced state of disrepair. For example, only about $15 \%$ of Dar es Salaam residents are connected to the city sewer network that was build in the late 1950s. The city has 8 oxidation ponds, of which only 4 are. in operation (University of Dar-es-Salaam, Kurasini, Mikocheni; and Vingunguti). Over $80 \%$, of the households in the city use pit latrines and septic tanks. These frequently overflow, especially during the rains, contaminating water sources and increasing health risks in the neighborhoods. The Zanzibar sewerage system which dates back to the 1920 s serves only about $18 \%$ of the population. As in Dar es Salaam, waste from the town's residents is dump sewer networks as well as to avoid haphazard waste discharge.

The promotion of local awareness is key to the effective management of pollution and the health risk associated with the problem. For example, guidelines should be formulated on the design and construction of wells and pit latrines with the view to reduce pollution in periurban areas where these facilities are commonly used. The public should be advised on the health risks associated with using water from shallow hand-dug wells especially those facing the risk of contamination from pit latrines and should be discouraged from using such facilities. A monitoring program to study the fluctuation of groundwater levels and quality should be initiated in areas where shallow wells and pit latrines arc commonly used with the view to providing help for pollution and health risk management. The public should also be made aware of the health risks associated with seawater pollution such as the dangers of eating contaminated fish and shellfish and swimming in sewagecontaminated waters. 
Moreover, there is a paucity of information on water quality for a large pm1 of the coast of Tanzania. Such information is essential in setting up management strategies. To start with, priority should be given to filling gaps in areas where there is little or no data available before embarking on long-term studies. Conse quently short-term studies should take priority over long term monitoring programs. However, this should be decided on a case by case basis, as there are areas that urgently require monitoring of both pollution inputs and its effects on the natural environment.

Pollution in Tanzania has yet to reach alarming levels. However, given continuing population pressure and industrialization in the country as well as the presence of some hotspots along the coast, necessary steps need to be taken to preclude further deterioration of water quality in the country.

\section{References and Notes}

1. Van Bruggen, J.J. 1990. A preliminary study on cnvironmental pollution on Zanzibar. Zanzibar Environmental Study Series No.6. Commission for Lands and Environment, Zanzibar.

2. Machiwa, J. F. 1992. Anthropogenic pollution in the Oar es Salaam Harbour area, Tanzania. Mar. Pollut. Bull. 24,562-567.

3. Mohammed, S.M. 1990. Pollution by industry and other users of chemicals. Zanzibar Environmental Study Series, 2. Commission for Lands and Environment, Zanzibar. 33pp.

4. Mohammed, S.M. 1997. Wafer Quality Assessment in the Coastal Waters Fronting the Stone Town, Zanzibar. Dorsch Consult, Zanzibar (Part 1-3)

5. Stcinbach, A.B. 1974. Industry and Environment in the Msimhazi Valley Drainage, Dar es Salaam. East African Social Environment course, University of Oar es Salaam, $12 \mathrm{pp}$.

6. Ngoile, M.A.K., Challe, A.E. and Mapunda, R.R. 197R Aquatic pollution in Tanzania. Paper presented at the Sixth FAO/SIIJA Workshop on Aquatic Pollution in Relation to the protected of Living Resources. Nairobi and Mombassa, Kenya. 12 Junc-22 July, 1978. Rome, FAO, Doc. FIR: tplr/78/inf. 19

7. Shanmungam, AT. 1981. Ports development in Tanzania and their impact on marine environment. Paper presented to United Nations/East African Workshop Oil Resources Policy and Management in Coastal/Marine Zones. October, 1981. Tanzania Harbours Authority, Dar es Salaam, $15 \mathrm{pp}$.

8. Shanmungam, AT 1983. The control of oil pollution in Tanzania coast. In: The Current State and development of Marine Sciences in Tanzania. Zanzibar, 2-8 April, 1982. Mainoya, J.R., Bwathondi, P.OJ. and Pratap, H.B. (eds), pp. 45-54

9. UNIOO/UNLI'. 1982. Industrial sources of marine and coastal pollution in the East African region. ENEP Regional Seas Reports and Studes No. 41.

10. Kondoro. J.W.A. 1997. Dispersion of heavy metals along Msimbazi River basin in Dar es Salaam, Tanzania. Tanzania J. Sci. 23, 1-10.

11. Wekwe, W.W., Othman. O.C. and Khan, M.R. 1989 Seaweeds as heavy metal pollution indicators. In: Environmental Pollution and its Management in Eastern Africa. Khan, M.R. and Gijzan, H.J. (eds) University of Dar es Salaam, Dar es Salaam, pp. 241 248.

12. Machiwa, J.F. 1992. Heavy metal content in coastal sediments off Dar es Salaam, Tanzania. Environ. Internal. 18, 409-415.

13. Mohammed, S.M., Ngusaru, A.S. and Mwaipopo, O.U. 1993. Determination of the Effects of Pollutant on Coral

Reef Areas Around Zanzibar Town. Report submitted to

National Environment management Council, Dar es Saaam.

14. Walvood, M.A. 1993. Environmental Impact Study of Sewage Pollution Along the West Coast of Zanzibar Town SIT. 39 pp.

15. Johnstonc. R. and Suleiman, M. 1997. Some aspects of the interaction between pollution and nutrient dynamics on coral reefs around Zanzibar. In: Proc. National Conference on Coral Reef. Zanzibar, 2-4 December, 1997. Johnstone, R.W., Francis, J. and Muhando, C.A (eds). pp. 45-50.

16. Mmochi, A.J. and Francis, J. 1999. Long-term Monitoring of Water Quality in Zanzibar. Tanzania. Institute of Marine Sciences, Zanzibar. 31 pp.
17. Mmochi, A.J. 1997. Pesticide and nutrient pollution of the ground water outflow to the nearshore water of Zanzibar Island, the case of Chwaka Bay, Pajc, Fumba and Makoba Bay. In: First Annual Progress Report of the INCO Project: Anthropogenically Induced Change in Groundwater Outflow and Quality, and the Functioning of Eastern African Nearshore Ecosystem. (GROFLO) pp. 117-122.

18. Mmochi, AJ. 1998. Pesticide and nutrient pollution of the ground water outflow to the nearshore water of Zanzibar Island, the case of Chwaka Bay, Paje, Fumba and Makoba Bay. In: Second Annual Progress Report of the INCO Proiect: Anthropogenically Induced Changes in Groundwater Outflow and Quality, and the Functioning of Eastern African Nearshore Ecosystem (GROFLO) pp. 54-56.

19. Machiwa, J.F. 1999 Distribution and remineralisation of organic carbon in sediments of a mangrove stand partly contaminated with sewage waste. Ambio 27, 740-744.

20. Uronu, W.E.M. 1995, Sewerage Issues in the Dar es Salaam area. In: Proc. National Workshop on Integra led Coastal Zone Management in Tanzania. May 8-12. The World Bank Land, Water, and Natural-Habitats Division Environmental Department.

21. Martinez, C. 1998. An Assessment of the Attemptss to Manage the Sewerage/Sanitation System or a Growing East African Coastal City Dar es Salaam, Tanzania. University of Rhode Island, $18 \mathrm{pp}$.

22. Bryceson, I., De Souza, T.F., Jehangeer, I, Ngoile, M.A.K. and Wynter, P. 1990. State of the marine environment in the Eastern African region. UNEP Regional Seas Reports and Studies No. 113,

23. Bryceson, I. 19R I. A review of some problems of tropical marine conservation with particular reference to the Tanzanian coast. Biol. Conserv. 20,163-171.

24. Mgana. S. and Mahongo, S. 1997. Land-based sources and activities affecting the quality and uses of the marine, coastal and associated freshwater environment: Tanzania Mainland. Report presented at the UNEP Regional Workshop, Institute of Marine Sciences, Zanzibar. 6-9 October. $1997.50 \mathrm{pp}$.

25. Mohammed, S.M. 1997. Land Based Sources and Activities Affecting the Coastal, Marine and Associated Freshwater Environment Along the Coast of 2anzihar. FAO. 18 pp.

26. Bwathondi, I'.OJ., Nkotagu, S.S. and Mkuula, S. 1991. Pollution of the Msimbazi Valley. Report commissioned by National Environment Management Council (NEMC), Dar es Salaam, 28 pp.

27. Mashauri, D.A and Mayo, A,1989: The Environmental impact of industrial and domestic wastewater in Dar es Salaam. In: Symposium on Environmental Pollution and Management in Eastern Africa. Faculty of Science, University of Dar es Salaam. 11-14 September 1989, pp. 90-101.

28. Shilungushela, J.M.S. 1993. Inventory of Destructive Activities to the Freshwater Bodies and the Marine Environment Along the Tonga Region Coastal Area. Report commissioned by National Environmen Management Council (NEMC), Dar es Salaam, $57 \mathrm{pp}$

29. Mmochi, A.J. and Mberek, R.S. 1998. Trends in the types, amounts and toxicity of pesticides used in Tanzania: Efforts to control pesticide pollution in Zanzibar. Ambio 27, 669--676.
30. Bjork, M., Mohammed, S.M., Bjorklund, M. and Semesi, A. 1995. Corraline algae, important coral reef builders threatened by pollution. Ambio 24,502-503.

3 I. Kangwc, J. W. 1999. The Effect or Land Based pollution on Reef Building Calcareous Algae in the Reef Near Zanzibar Town. MSc Thesis. University of Dar cs Salaam, Tanzania. $97 \mathrm{pp}$.

32. Bryceson, I. 1982. Pollution of Dar es Salaam coastal environments by industrial and domestics effluents. In: Proc. Workshop on the Current State and Development or Marine Sciences in Tanzania. Institute of Marine Sciences, Zanzibar. 2-8 April, 1982, pp. 32-41.

33. Chande, A.I. 1994. Inventory of Destructive Activities Affecting the Aquatic Environment: Mtwara Region. National Environment Management Council, Dar cs Salaam, 38 pp.

34. Shunula, J.P. and Ngoile, M.AK. 1989. Consequences of human activities on the marine environment of Zanzibar. In: Environmental Pollution and its Management in Eastern Africa. University of Dar es Salaam, Dar cs Salaam. 11-15 September, 1989, Khan, M.R. and Gizjen, 1-1..1. (cds). pp. /34-151.

35. Bryceson, I. 1983. Pollution of Dar es Salaam coastal environments by industrial and domestic effluents. In: Status and Problems of Marine Resources Development in Tanzania: Recommendations and Selected Papers from the Workshop on "The Current State and Development: or Marine Sciences in Tanzania." Zanzibar, 2-8 April, Mainoya, J.R., Bwathondi, P.O.J. and Pratap, H.B. (eds). pp. 32-41.

36. Mohammed, S.M. and Francis, J. 2001. The Regional Annex to the Recommended Framework for Decision Making: East Africa Region. IMS/ University of Dar es Salaam 40 pp.

Salim M. Mohammed Institute of Marine Sciences Zanzibar E-mail:.mlim@ims.lIdsm.ac.tz 